\title{
NEW SPECIES OF THE GENUS CHONDROSTOMA AGASSIZ, 1832 (ACTYNOPTERIGII, CYPRINIDAE) FROM WESTERN PORTUGAL
}

\author{
J. I. Robalo ${ }^{1}$, V. C.Almada ${ }^{1}$, C. Sousa Santos ${ }^{1}$, \\ M. I. Moreira ${ }^{2} \&$ I. Doadrio ${ }^{3}$
}

\begin{abstract}
A new cyprinid species endemic to western Portugal, Chondrostoma occidentale sp. n., is described based on fish collected in the small costal drainages of the Rivers Alcabrichel, Sizandro and Safarujo. The new species belongs to a monophyletic clade that also includes $C$. oligolepis and $C$. arcasii, with which it shares many molecular and morphological features. However, it can be distinguished from these two Chondrostoma species by a combination of the following characters: $40-43(x=40.9)$ canaliculate scales on the lateral line; 6-7 $(\bar{x}=6.9)$ above the lateral line; $2-3(\bar{x}=2.9)$ scales below the lateral line. The axilary pelvic scale is smaller than or at most equal to the base of the pelvic fin. The coronoid process of the dentary is very thick. The minimum divergence distances in cytochrome $b$ between $C$. occidentale and $C$. oligolepis and $C$. arcasii was $" p "=4.8-5.9 \%$. This new species should be considered Critically Endangered (CR) according to the IUCN Red List Categories.
\end{abstract}

Key words: cyprinids, Chondrostoma occidentale, western Portugal, taxonomy.

\section{RESUMEN}

Nueva especie del género Chondrostoma Agassiz, 1832 (Actynopterigii, Cyprinidae) del oeste de Portugal

Se describe una nueva especie de ciprínido endémico del oeste de Portugal, Chondrostoma occidentale sp. n., sobre la base de peces colectados en las pequeñas cuencas costeras de los ríos Alcabrichel, Sizandro y Safarujo. La nueva especie comparte algunas características geneticas y morfologicas con $C$. oligolepis y $C$. arcasii con los cuales forma un grupo monofiletico. Se puede diferenciar de estas dos especies de Chondrostoma por una combinación de los siguientes caracteres: $40-43(\bar{x}=40,9)$ escamas acanaladas en la línea lateral; 6-7 $(\bar{x}=6,9)$ escamas por encima de la línea lateral; $2-3(\bar{x}=2,9)$ por debajo de la línea lateral. La escama axilar es más corta o igual a la inserción de la aleta pelviana. El proceso coronoideo del dentario es muy robusto. La mínima distancia de divergencia para el citocromo b entre $C$. occidentale y otras especies de Chondrostoma fue de " $p "=4,8-5,9 \%$. Esta nueva especie debe ser considerada En Peligro Crítico (CR) de acuerdo con las categorías de la lista Roja de la UICN.

Palabras clave: Ciprínidos, Chondrostoma occidentale, oeste de Portugal, taxonomía.

Unidade de Investigação em Eco-Etologia. Instituto Superior de Psicologia Aplicada, 34. 1149-041 Lisboa. Portugal. jrobalo@ispa.pt

R. Dr. Jacinto Nunes, 15. 2775-206 Parede. minesmoreira@clix.pt

Museo Nacional de Ciencias Naturales. José Gutiérrez Abascal 2. 28006 Madrid. Spain. mond147@mncn.csic.es 


\section{Introduction}

The Iberian Peninsula harbours a very diverse cyprinid fauna with most species being endemic (Doadrio, 2001). A substantial proportion of this diversity corresponds to fish of the genus Chondrostoma (sensu Zardoya \& Doadrio, 1999) with at least 11 described endemic species (Doadrio \& Carmona, 2003) and some others awaiting formal description (e.g. Carmona et al., 2000; Mesquita et al., 2001). A monophyletic clade has been recognized for a long time in this genus (Zardoya \& Doadrio, 1998; Doadrio, 2001) comprising two species formerly included in the genus Rutilus Rafinesque, 1820, Chondrostoma arcasii (Steindachner, 1866) and Chondrostoma macrolepidotum (Steindachner, 1866) (the name of this species was preoccupied by Leuciscus macrolepidotus Ayres 1854 and a new replacement name has been provided for C. macrolepidotum (Steindachner, 1866) by Robalo et al., 2005 as Chondrostoma oligolepis Robalo, Doadrio, Almada \& Kottelat, 2005). These two species have proved difficult to distinguish due to some overlap in many morphometric and meristic characters and have been the subject of several comparative studies (Casado, 1995; Collares-Pereira, 1979, 1983; Zardoya \& Doadrio, 1998). CollaresPereira (1983) showed that $C$. arcasii is almost absent in Portugal, excepting perhaps the basin of the Miño River and some populations in the Távora River, a tributary of the left margin of the Duero basin. Thus, according to Collares-Pereira (1983) the distribution of $C$. oligolepis, ranges from the basin of the Limia River (in north-western Portugal) south to the Alcoa River (located between the cities of Leiria and Lisbon). This species is also present in the Nabão River (Tagus basin). However, subsequent field work showed that $C$. oligolepis is also present to the south of the Alcoa River, in the small independent coastal drainages of Real and Alcabrichel Rivers (Diogo, 1999).

Chondrostoma arcasii is mainly distributed in Spain, ranging from the basin of the River Ulla in the north-western area of the Iberian Peninsula (Galicia) eastwards to the basin of the River Júcar in the Mediterranean slope, and being present in the large basins of the Duero, Tagus and Ebro (Doadrio, 2001).

In a survey of the clade $C$. arcasii $-C$. oligolepis encompassing all its geographical distribution in Portugal and Spain, the authors of the present work (Robalo et al., in press) could confirm with molecular data (sequences of the mitochondrial cytochrome $b$ gene) that $C$. oligolepis ranges from the River Limia south to the River Tornada. However, to the south of this area, in the small rivers Alcabrichel, Sizandro and Safarujo, the same authors found populations of the genus Chondrostoma, belonging to the oligolepis - arcasii clade, in which the cytochrome $b$ sequences were very divergent from the previously known species. Doadrio \& Carmona (2004) published evidence that corroborates this conclusion.

In this paper, we present evidence showing that the features of these populations warrant their inclusion in a new species and give its formal description.

\section{Material and Methods}

For morphometric purposes we studied the following material of $C$. oligolepis, belonging to the collection of UIE/ISPA: 18 individuals from Limia basin, 15 individuals from Mondego basin, 20 individuals from Tornada basin and 17 individuals from Alcoa basin. Syntipes from C. oligolepis, deposited in the collections of Naturhistorischen Museum Wien (NMW 49815: 1-4, although only three syntypes are mentioned by Steindachner in the description), were also analysed. As far as $C$. arcasii is concerned, 23 individuals from the River Adaja in the Duero basin (Spain) were studied from the collections of Museo Nacional de Ciencias Naturales (MNCN 156860-157023). The material of Chondrostoma nov sp included a total of 60 adults: 48 from the Sizandro basin and 12 from the Safarujo basin. Although the genetic comparisons showed that the population of Alcabrichel belongs to the same monophyletic clade that includes the populations of Sizandro and Safarujo (Doadrio \& Carmona, 2004; Robalo et al., in press) we didn't find preserved specimens from Alcabrichel suitable for morphometric and meristic analysis.

From this material we selected 24 individuals as type series, deposited in Museo Nacional de Ciencias Naturales (MNCN), Madrid, Spain. Additional material is deposited in Instituto Superior de Psicología Aplicada (ISPA), Lisboa, and in Museu Nacional de Historia Natural, Lisboa, Portugal.

The diagnostic and description are based on the material of the type series.

For a schematic representation of the locations of the drainages from which fish were analysed see Figure 1.

The morphological comparisons involved only fish of the new species and C. oligolepis and C. arca- 


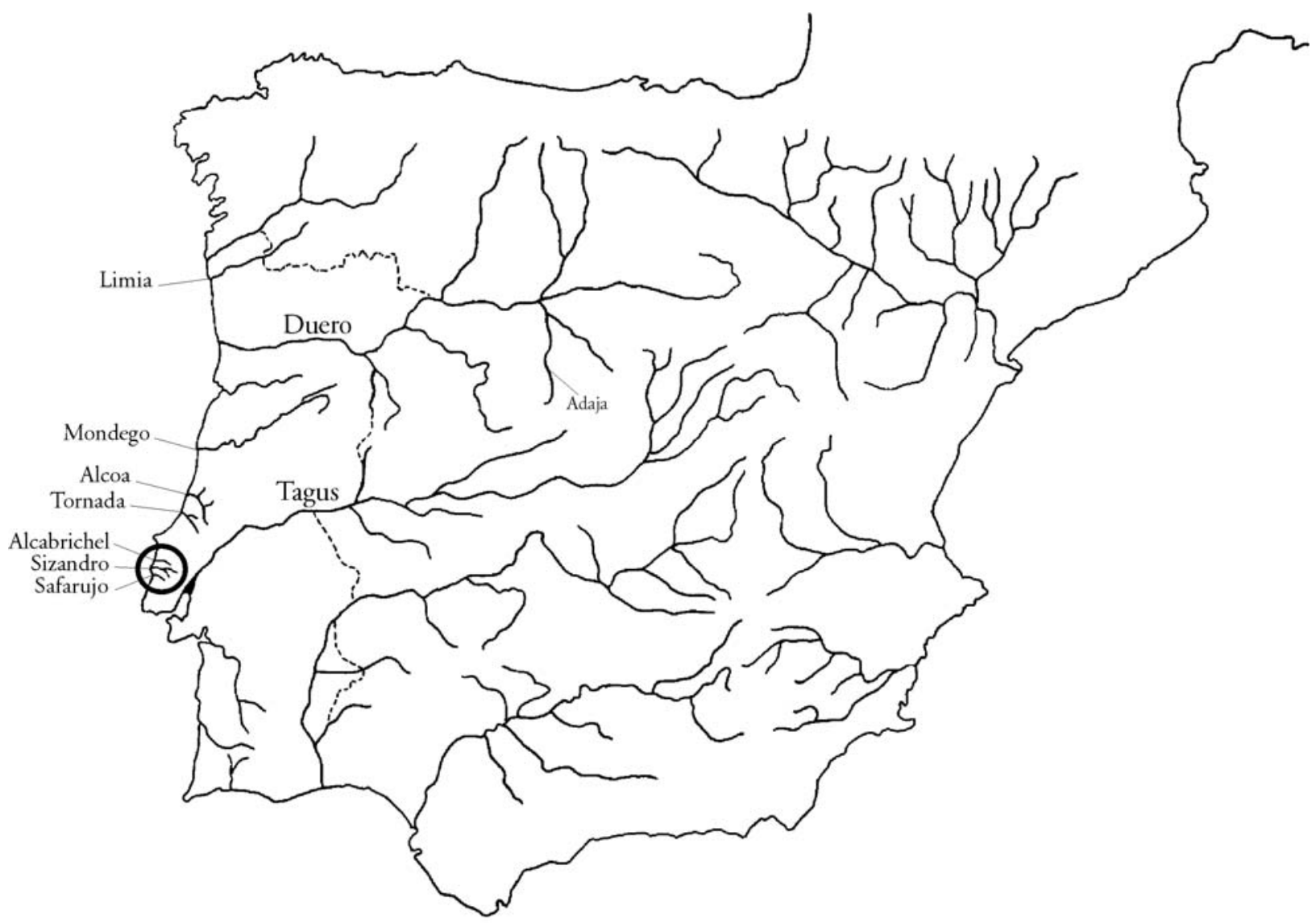

Fig. 1.- Schematic map of the Iberian Peninsula indicating the locations of the drainages mentioned in the text.

Fig. 1. - Mapa esquemático de la Península Ibérica donde se indica la localización de las cuencas mencionadas en el texto.

sii, because previous genetic studies (Doadrio \& Carmona, 2004; Robalo et al., in press) had shown that they belong to a very well supported monophyletic clade. In turn, Zardoya \& Doadrio $(1998,1999)$ had shown, with genetic data, that this clade, although lacking the horny blade on the lower lip characteristic of the genus Chondrostoma (as defined by Elvira, 1987, 1997), must be included in this genus, which emerges as a very robust monophyletic group. This finding prompted the transfer of these species from the genus Rutilus to the genus Chondrostoma. Thus, we limited our comparisons to $C$. oligolepis and $C$. arcasii because they are the species of Chondrostoma that are genetically and morphologically closest to the new species and the ones from which its differentiation had to be demonstrated.

For genetic purposes we studied 6 individuals of Chondrostoma nov sp and 8 individuals of C. oli- golepis. As the northern limit of the distribution of C. lusitanicum Collares-Pereira, 1980 is located a few kilometres to the south of the River Safarujo (Collares-Pereira, 1983; Costa Pereira, 1995) we decided to include three samples of $C$. lusitanicum from the rivers nearest to our study area, to avoid possible confusion between our fish and C. lusitanicum, another small bodied member of the genus Chondrostoma, that also lacks the horny blade in the lower lip.

For osteological purposes we studied the following material: $C$. arcasii: 18 individuals from Queiles River (Ebro Basin), 3 individuals Abion River (Duero Basin), 3 individuals Pedro River (Duero Basin), 1 individual Ontigola Lagoon (Tajo Basin), 1 individual Gritos River (Júcar Basin). Chondrostoma oligolepis: 2 individuals Alcoa River (Alcoa Basin), 2 individuals Mondego River 
(Mondego Basin). Chondrostoma nov. sp.: 1 individual Safarujo River (Safarujo Basin), 2 individuals Sizandro River (Sizandro Basin).

Data collection. All fish of Chondrostoma nov $\mathrm{sp}$ were collected for the present study. Part of the material was collected by electrofishing. To enable us to use live fish, animals where anesthetized with a weak solution of MS222. They were placed on a white surface and lateral views of the specimens where taken with a SONY DSC-S75 digital camera. A small piece of fin was clipped off for genetic analysis and the basic meristic characters were determined. After being placed in clean water more than $99 \%$ of the fish fully recovered. To allow direct comparison between live and preserved specimens the fish from the MNCN where photographed with the same camera in lateral view.

Morphology. Meristics. The following meristic characters were compared: canaliculate scales of the lateral line (SLL), scales of the upper transverse row (SUTR), scales of the lower transverse row (SLTR), branched dorsal fin rays (DR) and branched anal fin rays (AR). In addition, the following characters were analysed in the type series used to describe the new species: pectoral fin rays (PR), ventral fin rays (VR), pharyngeal teeth (PT), gill rackers (GR), abdominal and caudal vertebrae.

MORPHOMETRY. Morphometric data were collected from the digital pictures using the software package IMAGE tool (UTHSCSA V. 3.00), using the standard length (SL) of the fish taken at the time of photographing to calibrate all measurements.

The pictures that yielded doubtful measurements, either because a preserved specimen was deformed or because the picture had poor quality were discarded.

Fourteen morphometric variables were analysed. The following abbreviations were used for these morphometric characters: SL, standard length; HL, head length; $\mathrm{HH}$, head height; PrOL, preorbital length; ED, eye diameter; PsOL, postorbital length; DOP, distance measured on a vertical line from the upper edge of the orbit to the upper limit of the head; PrDD, predorsal distance; PrVD, preventral distance; PrAD, preanal distance; $\mathrm{MHCP}$, minimum height of the caudal peduncle; BDP, body depth at the level of the insertion of pectoral fins; BDA, body depth at the level of the insertion of anal fins and HA, angle centred at the tip of the snout formed by the straight lines that go from there to the highest and lowest points of the head. The relative size of the axilary pelvic scale was qualitatively evaluated whenever possible. In addition, the following measurements were also performed on the type material: PrPD, prepectoral distance; CPL, caudal peduncle length; APL, anal peduncle length; PVL, pectoralventral length; VAL, ventral-anal length; DFL, dorsal fin length; DFH, dorsal fin height; PFL, pectoral fin length; VFL, ventral fin length; AFL, anal fin length; AFH, anal fin height; CFL, caudal fin length; BD body depth.

Differences in body shape between populations were analysed using discriminant analysis. Since indices may not vary linearly with size, causing differences of size to yield false differences between populations, we decided to use as raw data residuals of log-log regressions of the variables, using the standard length (SL) of the fish as the independent variable (Oliveira \& Almada, 1995). HA was not subjected to this transformation since it is an angular measure. Residuals of the regressions where used to perform a discriminant analysis, in which the new species was compared to $C$. arcasii and $C$. oligolepis. A discriminant analysis was also performed separately on the meristic data. As the discriminant analysis depended on residuals of relationships of the morphometric characters with standard length, some proportions important to the characterization of the shape of the fish were not captured and were compared separately. These comparisons were performed using Mann-Whitney $\mathrm{U}$ Test and adopting a significance level of $\mathrm{p}<0.05$. To compensate for the performance of multiple comparisons, Bonferroni corrections were applied to all analyses. All these statistical procedures were performed using STATISTICA (V. 5.5, StatSoft, 1996).

Osteology. The osteological characters were studied from cleared and stained specimens (Wassersug, 1976).

GeNETICS. Total genomic DNA was extracted from a piece of fin clip or muscle by the standard proteinase $\mathrm{K}$ and phenol/chloroform extraction method (Sambrook et al., 1989). A total of $1140 \mathrm{bp}$ of the cytochrome $b$ gene was amplified using the primers presented by Machordom \& Doadrio (2001). Details of DNA extraction, PCR and sequencing may be requested from the authors. The details of the procedures and the results of the molecular analyses will be published elsewhere (Robalo et al., in press).

After alignment with Clustal X (Thompson et $a l .$, 1997), distances between samples were compu- 


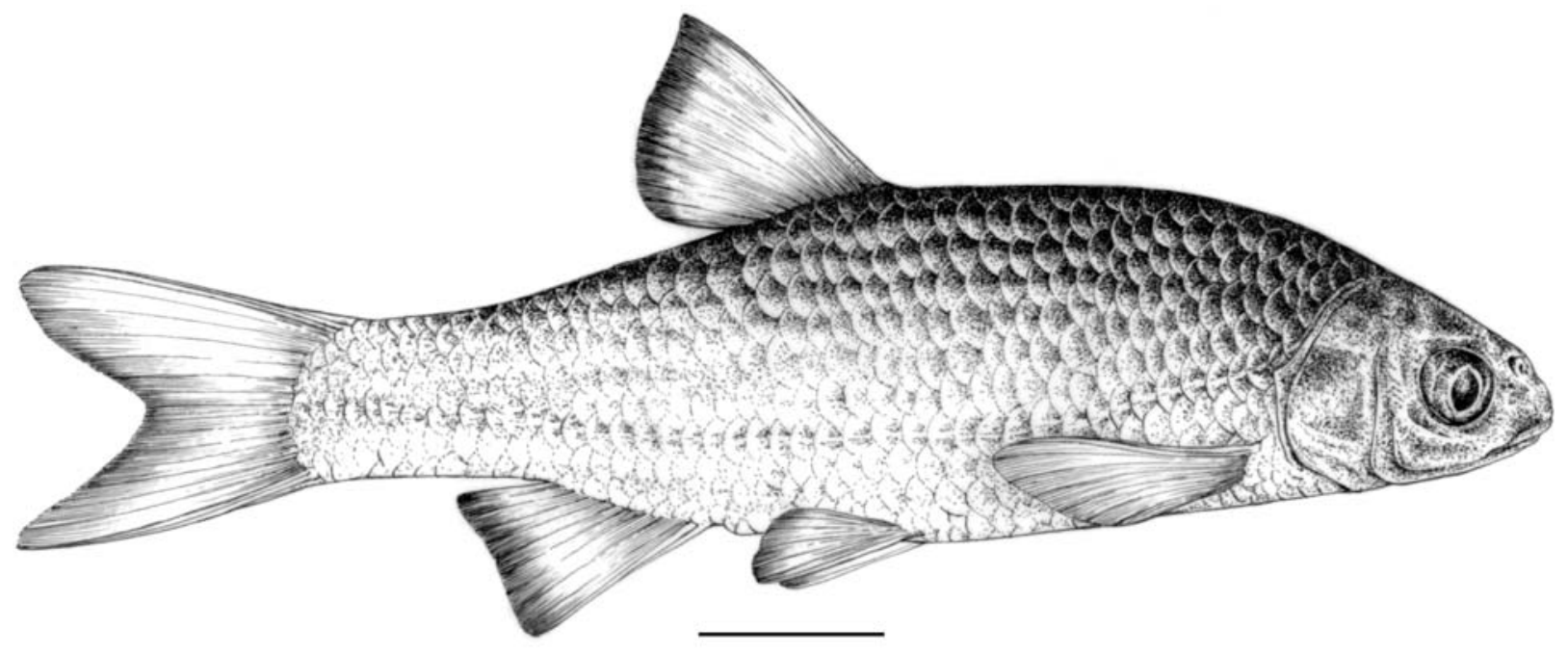

Fig. 2.- Chondrostoma occidentale sp. nov. Holotype. MNCN244125. $72.5 \mathrm{~mm}$ SL. Safarujo River, Mafra, Safarujo basin, Portugal.

Fig. 2.-Chondrostoma occidentale sp. nov. Holotipo. MNCN244125. 72.5 mm SL. Río Safarujo, Mafra, cuenca del río Safarujo, Portugal.

ted with PAUP* 4.0 (Swofford, 1998). AMOVA was performed using Arlequin version 2.0 (Schneider et al., 2000) in order to compare the samples of the fishes from Alcabrichel, Sizandro and Safarujo Rivers with $C$. oligolepis, the only member of the clade that occurs in the vicinity of these drainages.

\section{Results}

The discriminant analysis of the meristic data yielded highly significant results (Wilks' Lambda $\left.=0.11 ; \mathrm{F}_{(8,294)}=73.53 ; p<0.00001\right) .85 \%$ of Chondrostoma nov sp where correctly classified, with only 5 misclassifications involving $C$. oligolepis and Chondrostoma nov sp, 4 misclassifications between this group and $C$. arcasii and none between $C$. oligolepis and $C$. arcasii.

Discriminant analysis of the morphometric data also yielded robust results (Wilks' Lambda $=0.17$; $\left.\mathrm{F}_{(30.206)}=9.82 ; p<0.00001\right) .95 \%$ of Chondrostoma nov sp where correctly classified, with 2 misclassifications between C. oligolepis and Chondrostoma nov sp, 1 misclassification between Chondrostoma nov sp and $C$. arcasii and none between $C$. oligolepis and C. arcasii.

Concerning genetic comparisons, the within group average $p$ distance was $0.27 \%$ for $C$. lusita- nicum $(\mathrm{n}=3), 0.45 \%$ for $C$. oligolepis $(\mathrm{n}=8)$ and $0.28 \%$ for Chondrostoma nov sp $(\mathrm{n}=6)$. C. occidentale had a between group distance of $5.83 \%$ with $C$. oligolepis, which is of the same order than that between many widely recognized pairs of cyprinid fish species (Zardoya \& Doadrio, 1998, 1999). The distance between Chondrostoma nov sp and $C$. arcasii is of similar order than that between C. occidentale and C. oligolepis. This distance is even greater than that between $C$. arcasii and $C$. oligolepis (Robalo et al., submitted). The distance of Chondrostoma nov sp to C. lusitanicum is much greater, $9.78 \%$.

The results of AMOVA were highly significant and showed that the variation between $C$. oligolepis and Chondrostoma nov sp was much higher than that within groups $(95.19 \%$ and $4.81 \%$, respectively, $\left.\mathrm{F}_{\mathrm{ST}}=0.95, p<0.00001\right)$. In addition, not a single haplotype was shared between the two groups.

\section{Chondrostoma occidentale, new species} (Figure 2)

Holotype: MNCN244125. $72.5 \mathrm{~mm}$ SL. Safarujo River, Mafra, Safarujo basin, Portugal. Leg. V. Almada, J. Robalo, C. Santos. 9.X.2002.

PARATYPES: MNCN244123, 1 individual Safarujo River. Mafra, Safarujo basin, Portugal. Leg. V. Almada, J. Robalo, C. Santos. 
9.X.2002. MNCN244127-128, 2 individuals Sizandro River, Torres Vedras, Sizandro Basin, Portugal. Leg. V. Almada, J. Robalo, C. Santos. 9.X.2002. MCN246658-677, 20 individuals, Sizandro River, Torres Vedras, Sizandro Basin, Portugal. Leg. V. Almada, I. Doadrio, P. Garzón, J. Robalo, C. Santos.

DiAgnosis: Chondrostoma occidentale is a member of the $C$. arcasii - $C$. oligolepis species group. This group of arched mouth fish lacks the horny blade on the lower lip and has a lateral line scale which is much lower than other bladeless species of Chondrostoma ( $<45$ on lateral line). Chondrostoma occidentale differs from $C$. arcasii and $C$. oligolepis by the following combination of characters: $40-43(\bar{x}=40.9)$ canaliculate scales on the lateral line; $6-7$ scales $(\bar{x}=6.9)$ above the lateral line; $2-3(x=2.9)$ scales below the lateral line (see Table 1). Axillary pelvic scale shorter than or equal to the insertion of the pelvic fin. The coronoid process of the dentary is very thick (Figure 3 ). The minimum divergence distances in cytochrome $b$ between $C$. occidentale and the remaining members of the group was " $p$ " $=4.8-5.9 \%$. The body proportions that differed significantly in $C$. occidentale, either from C. oligolepis and/or C. arcasii are presented in Table 2 .

DESCRIPTION: DR III $\bar{x}=6.9 \pm 0.3$ (7-8), AR III $\bar{x}=6.9 \pm 0.3$ (6-7), PR I 12-13, VR I 7-8, SLL $\bar{x}$ $=40.9 \pm 0.9(40-43)$, SUTR $x=6.9 \pm 0.37$ (6-7), SLTR $\bar{x}=2.29 \pm 0.30(2-3)$, PT 5-5, GR $\bar{x}=13.6$ \pm 0.4 (12-14), 20-21 abdominal vertebrae, 17 caudal vertebrae. Morphometric and meristic characters of the type material are given in Table 1. A small sized species that rarely reaches $100 \mathrm{~mm}$ of standard length.

In Table 2 the meristic and morphometric characters of $C$. occidentale are contrasted with those of $C$. oligolepis and $C$. arcasii to help the characterization of the new species. In this table, information on $C$. occidentale includes that of the type series and all other specimens analysed.

When we state that a given count or ratio for $C$. occidentale is greater or smaller than in other species we are only considering data that are statistically significant.

Although there is some overlap in the meristic characters between $C$. occidentale and the two other species compared in this study, all scale counts are significantly different, both between $C$. occidentale and C. oligolepis, and between $C$. occidentale and $C$. arcasii.

The body is elongated and moderately compressed. In terms of body shape $C$. occidentale is, in many respects, intermediate between $C$. oligolepis
Table 1.- Number of individuals, Means, Ranges and Standard deviations of the meristic and morphometric variables for $C$. occidentale paratypes and holotype. For abbreviations see the Material and Methods section.

Tabla 1.- Número de individuos, media, rango y desviación estándar de las variables merísticas y morfométricas del holotipo y los paratipos de C. occidentale. Las abreviaturas se indican en Material y Métodos.

\begin{tabular}{|c|c|c|c|c|}
\hline \multicolumn{5}{|c|}{ Chondrostoma occidentale nov. sp. } \\
\hline \multirow[t]{2}{*}{ Variable } & \multirow[t]{2}{*}{ Holotype } & \multicolumn{3}{|c|}{ Paratypes $(\mathrm{n}=23)$} \\
\hline & & Mean & Range & SD \\
\hline SLL & 42 & 40.9 & $40-43$ & 0.9 \\
\hline SUTR & 7 & 6.9 & $6-7$ & 0.3 \\
\hline SLTR & 3 & 2.9 & $2-3$ & 0.3 \\
\hline DR & 7 & 6.9 & $6-7$ & 0.3 \\
\hline AR & 7 & 6.9 & $6-7$ & 0.3 \\
\hline SL & 72.5 & 66.2 & $44.8-93.4$ & 14.0 \\
\hline $\mathrm{HL}$ & 17.5 & 15.7 & $11.5-22.1$ & 2.9 \\
\hline PrOL & 5 & 4.7 & $3.4-7$ & 0.9 \\
\hline ED & 5.1 & 4.2 & $3.2-5.3$ & 0.6 \\
\hline PsOL & 8.5 & 7.3 & $5.3-10.5$ & 1.4 \\
\hline ID & 8.5 & 5.9 & $3.7-8.3$ & 1.1 \\
\hline $\mathrm{HH}$ & 13.7 & 11.3 & $7.3-15.7$ & 2.2 \\
\hline PrDD & 40.2 & 35.1 & $22.6-52.2$ & 8.1 \\
\hline PrPD & 17.7 & 16.7 & $11.5-23$ & 3.3 \\
\hline PrVD & 35.3 & 32.9 & $22-47.2$ & 6.8 \\
\hline PrAD & 48.4 & 45.3 & $30.1-67$ & 10.1 \\
\hline CPL & 27.7 & 26.1 & $16.9-39.7$ & 6.0 \\
\hline APL & 15.3 & 15.0 & $9.8-22.7$ & 3.4 \\
\hline PVL & 16.5 & 15.1 & $9.7-21.5$ & 3.2 \\
\hline VAL & 11.2 & 10.7 & $6.8-15.8$ & 2.7 \\
\hline DFL & 9.1 & 7.1 & $5.1-10.4$ & 1.3 \\
\hline DFH & 15 & 12.6 & $8.9-16.5$ & 2.1 \\
\hline PFL & 15.3 & 12.6 & $8.5-17.1$ & 2.5 \\
\hline VFL & 12.9 & 10.7 & $6.6-14.3$ & 2.5 \\
\hline AFL & 8.6 & 6.9 & $4.3-9.1$ & 1.3 \\
\hline $\mathrm{AFH}$ & 11.7 & 11.0 & $7.3-15.2$ & 2.5 \\
\hline CFL & 15 & 12.5 & $8.2-17.9$ & 2.5 \\
\hline BD & 20 & 16.2 & $10.1-25$ & 3.7 \\
\hline MHCP & 7.8 & 7.2 & $4.8-9.9$ & 1.5 \\
\hline
\end{tabular}

and $C$. arcasii (Table 2). It differs from C. oligolepis, the species that is geographically closer, in the following characters: $C$. occidentale has a more elongated body, a feature that is expressed by the ratio $\mathrm{BDP} / \mathrm{SL}$. The head is lower and more elongated. The profile of the head and snout of $C$. occidentale tends to differ from that of $C$. oligolepis as expressed by the angle centred on the tip of the snout and formed by the straight lines that go from there to the highest and lowest points on the head (HA). This angle in $C$. 
Table 2.- Number of individuals, Means, Ranges and Standard deviations of the meristic variables and morphometric indices that yielded significant differences between Chondrostoma occidentale and C. oligolepis and between C. occidentale and C. arcasii. Signs of $>$ and $<$ in C. occidentale cells are oriented towards the species with which the corresponding measure has yielded a significant difference and represent the relation between these values. Only comparisons that yielded $\mathrm{p}<0.05$ after Bonferroni corrections were included. The ratio ED/SL was also included although there were no significant differences in comparisons of this ratio. It was kept in the table because if not properly controlled for this measurement other ratios could have become artificially biased. For abbreviations see the Material and Methods section.

Tabla 2.- Número de individuos, media, rangos y desviación típica de las variables merísticas e índices morfométricos para los que se encontraron diferencias entre Chondrostoma occidentale y $C$. oligolepis y entre $C$. occidentale y $C$. arcasii. Los símbolos $>\mathrm{y}<$ en las celdas de C. occidentale están orientados hacia la especie para la que esa medida produjo diferencias significativas y representan la relación entre esos valores. Sólo se incluyen las comparaciones que produjeron $\mathrm{p}<0.05$ después de la corrección de Bonferroni. La proporción ED/SL también se adjunta aunque no haya diferencias significativas y se conserva en la tabla porque otras proporciones podrían estar sesgadas artificialmente si no son adecuadamente controladas por esta medida. Para las abreviaciones ver el apartado de Material y Métodos.

\begin{tabular}{|c|c|c|c|c|c|c|c|c|c|c|c|c|c|c|}
\hline & \multicolumn{4}{|c|}{ C. oligolepis } & \multicolumn{6}{|c|}{ C. occidentale } & \multicolumn{4}{|c|}{ C. arcasii } \\
\hline & $\mathbf{N}$ & Mean & Range & Std. Dev. & & $\mathbf{N}$ & Mean & Range & Std. Dev. & & $\mathbf{N}$ & Mean & Range $S$ & Std. Dev. \\
\hline SLL & 70 & 38.10 & $35-41$ & 1.44 & $<$ & 24 & 40.91 & $40-43$ & 0.94 & $<$ & 23 & 44.83 & $43-48$ & 1.59 \\
\hline SUTR & 70 & 6.94 & $6-8$ & 0.42 & & 24 & 6.92 & $6-7$ & 0.31 & $<$ & 22 & 7.50 & $7-8.5$ & 0.49 \\
\hline SLTR & 70 & 2.89 & $2-3.5$ & 0.28 & $<$ & 24 & 2.95 & $2-3$ & 0.30 & $<$ & 23 & 4.28 & $4-5$ & 0.29 \\
\hline DR & 69 & 7.17 & $6-8$ & 0.42 & $>$ & 60 & 7.02 & $7-8$ & 0.13 & & 23 & 7.00 & 7 & 0.00 \\
\hline AR & 69 & 7.42 & $7-8$ & 0.50 & $>$ & 60 & 7.10 & $6-8$ & 0.35 & $>$ & 23 & 6.78 & $6-7$ & 0.42 \\
\hline ED/PROL & 52 & 1.25 & $0.63-1.73$ & 0.21 & $>$ & 51 & 1.13 & $0.85-1.39$ & 0.12 & $<$ & 12 & 1.25 & $1.08-1.45$ & 0.13 \\
\hline $\mathrm{HH} / \mathrm{SL}$ & 52 & 0.19 & $0.17-0.21$ & 0.01 & $>$ & 51 & 0.18 & $0.15-0.22$ & 0.01 & & 12 & 0.18 & $0.17-0.19$ & 0.00 \\
\hline $\mathrm{PrOL} / \mathrm{SL}$ & 52 & 0.06 & $0.04-0.07$ & 0.01 & & 51 & 0.06 & $0.04-0.07$ & 0.01 & $>$ & 12 & 0.05 & $0.04-0.06$ & 0.01 \\
\hline $\mathrm{ED} / \mathrm{SL}$ & 52 & 0.07 & $0.04-0.08$ & 0.01 & & 51 & 0.07 & $0.05-0.08$ & 0.01 & & 12 & 0.06 & $0.05-0.07$ & 0.01 \\
\hline PsOL/SL & 52 & 0.11 & $0.08-0.13$ & 0.01 & & 51 & 0.11 & $0.04-0.16$ & 0.01 & $<$ & 12 & 0.12 & $0.11-0.13$ & 0.01 \\
\hline DOP/SL & 52 & 0.03 & $0.02-0.05$ & 0.01 & $>$ & 49 & 0.02 & $0.01-0.04$ & 0.01 & & 12 & 0.02 & $0.01-0.03$ & 0.01 \\
\hline $\mathrm{MHCP} / \mathrm{SL}$ & 52 & 0.11 & $0.09-0.13$ & 0.01 & $>$ & 51 & 0.10 & $0.09-0.12$ & 0.01 & & 12 & 0.10 & $0.09-0.11$ & 0.01 \\
\hline $\mathrm{BDP} / \mathrm{SL}$ & 39 & 0.22 & $0.20-0.25$ & 0.01 & $>$ & 29 & 0.21 & $0.19-0.23$ & 0.01 & & 12 & 0.21 & $0.20-0.23$ & 0.01 \\
\hline $\mathrm{BDA} / \mathrm{SL}$ & 52 & 0.18 & $0.16-0.20$ & 0.01 & & 51 & 0.18 & $0.16-0.22$ & 0.01 & $>$ & 12 & 0.16 & $0.14-0.18$ & 0.01 \\
\hline $\mathrm{HH} / \mathrm{HL}$ & 52 & 0.83 & $0.72-0.99$ & 0.05 & $>$ & 51 & 0.79 & $0.63-1.00$ & 0.06 & & 12 & 0.77 & $0.69-0.85$ & 0.05 \\
\hline PrOL/HL & 52 & 0.24 & $0.19-0.35$ & 0.03 & & 51 & 0.25 & $0.20-0.37$ & 0.03 & $<$ & 12 & 0.22 & $0.19-0.25$ & 0.02 \\
\hline ED/HL & 52 & 0.30 & $0.22-0.35$ & 0.02 & $>$ & 51 & 0.28 & $0.21-0.38$ & 0.03 & & 12 & 0.27 & $0.24-0.30$ & 0.02 \\
\hline DOP/HL & 52 & 0.14 & $0.07-0.19$ & 0.03 & $>$ & 49 & 0.10 & $0.05-0.16$ & 0.03 & $>$ & 12 & 0.07 & $0.03-0.11$ & 0.02 \\
\hline HH/BDP & 39 & 0.87 & $0.79-0.95$ & 0.04 & $>$ & 29 & 0.84 & $0.76-0.90$ & 0.04 & & 12 & 0.84 & $0.77-0.87$ & 0.03 \\
\hline $\operatorname{PrAD} / \mathrm{SL}$ & 52 & 0.69 & 0.63-0.74 & 0.02 & $<$ & 51 & 0.70 & $0.62-0.73$ & 0.02 & & 12 & 0.70 & $0.68-0.75$ & 0.02 \\
\hline HÁ & 53 & 59.09 & $52.24-63.58$ & 2.99 & $>$ & 55 & 55.82 & $47.53-60.46$ & 3.31 & & 12 & 56.20 & $52.95-60.11$ & 1.97 \\
\hline
\end{tabular}

occidentale is usually smaller than in $C$. oligolepis and it is even smaller in C. arcasii. The eyes tend to be located higher on the head. They are also located more posteriorly than in C. oligolepis and in C. arcasii, as shown by the ratio $\mathrm{ED} / \mathrm{PrOL}$. As the ratio ED/SL did not differ significantly between $C$. occidentale and C. oligolepis (see Table 2) the relationships considered above are not artificially caused by differences in eye diameter. Taken together, these proportions mean that $C$. occidentale has as more pointed and long snout than $C$. oligolepis.

The height of the caudal peduncle is contained 8.61-11.41 $(\bar{x}=9.78)$ times in the standard length. The caudal peduncle is proportionately and signifi- cantly narrower than in C. oligolepis. In C. occidentale, the insertion of the anal fin is located more posteriorly than in C. oligolepis.

Pigmentation Pattern: The general pattern of coloration in $C$. occidentale is, broadly speaking, similar to those of $C$. oligolepis and $C$. arcasii. In the three species, the body is darker above the lateral line than bellow, a yellow iridescent band runs along the flanks and there is reddish pigmentation at the base of all fins, especially on the paired ones. In $C$. occidentale there are, however, details of the colour pattern that distinguish it from C. oligolepis and $C$. arcasii. The upper part of the body is much 
A
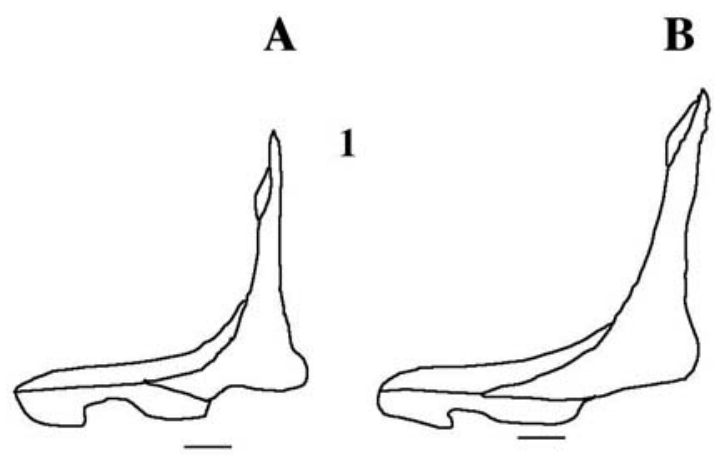

2
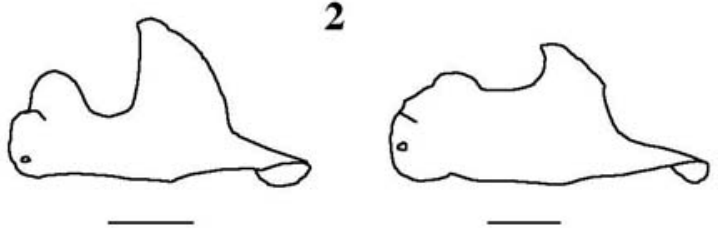

3

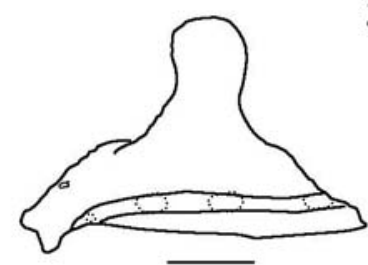

B
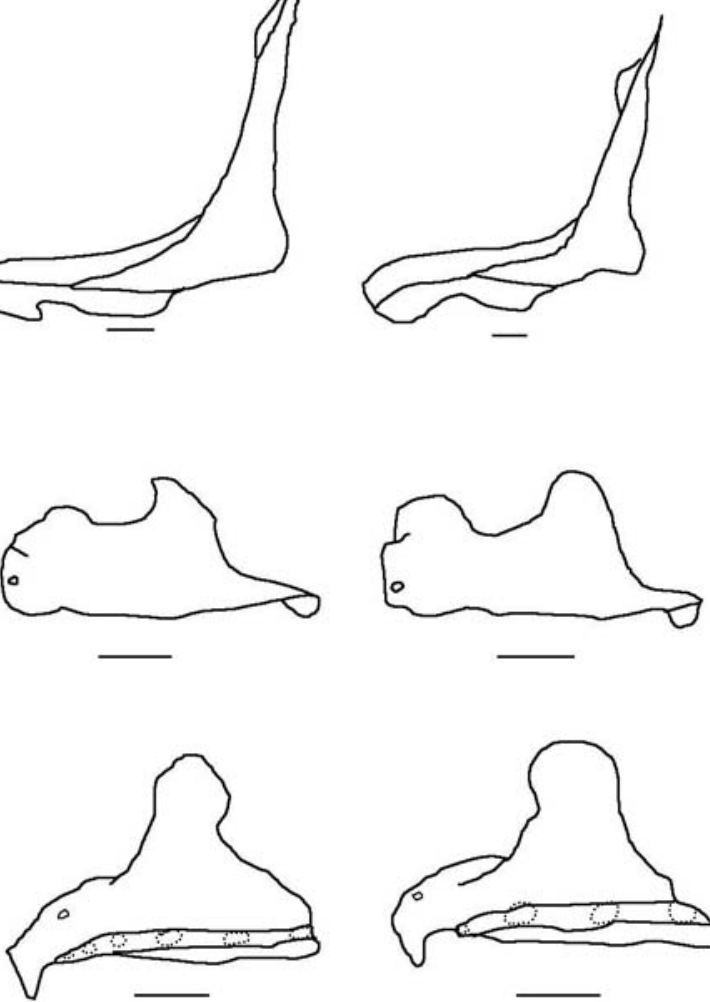

C

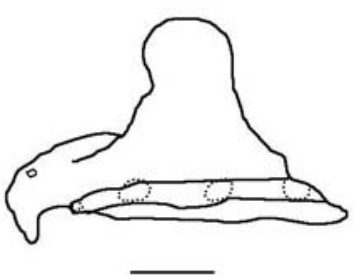

Fig. 3.- Osteological characters of the cleithrum (1), maxilla (2) and dentary (3) of Chondrostoma arcasii (A), C. oligolepis (B) and C. occidentale sp. n. (C). Scale bar: $1 \mathrm{~mm}$.

Fig. 3. - Caracteres osteológicos del cleitro (1), maxilar (2) y dentario (3) de Chondrostoma arcasii (A), C. oligolepis (B) and C. occidentale sp. n. (C). Escala: $1 \mathrm{~mm}$.

lighter than in C. oligolepis, C.arcasii showing the darkest pattern. The pigmentation along the lateral line in $C$. occidentale is less conspicuous than in the remaining species of the group and the pigmentation at the base of the fins is lighter and more orange than red. Below the lateral line, the body is brighter, presenting a silvery hue.

Osteology: Concerning osteology the only interspecific differences found are referred below.

The superior process of the cleithrum is narrower than in $C$. arcasii and C. oligolepis. In the maxilla the small palatine process is similar to that of C. oligolepis. As regards the dentary, the coronoid process is considerably thicker than in the other two species. The number of pores of the dentary varies between 2 and 3, being similar to $C$. arcasii (Figure 3).
ETymology: The area of Portugal where this species occurs is known as the Oeste, meaning West in English. The latin name occidentale emphasizes the fact that this species is endemic to this region.

Distribution: The species is endemic to Estremadura, central western Portugal and is restricted to the rivers Sizandro, Safarujo and Alcabrichel.

Common Name: Ruivaco do Oeste.

REMARKS: The rivers where $C$. occidentale is found are small coastal streams that have a greatly reduced water flow in the dry summer period. In this situation, the fish become concentrated in a few pools where they seek shelter in shady areas under the cover of vegetation. 
Aquarium observations (Robalo, unpublished) showed that $C$. occidentale forms spawning aggregations shedding eggs near stones and vegetation. The eggs are adhesive. Breeding occurs in spring, specially in late April and May, when ripe fish were also collected in the field.

Chondrostoma occidentale is the only cyprinid fish occurring in these streams. The only fish collected with $C$. occidentale were Cobitis paludica and Anguilla anguilla.

CONSERVATION: The populations of the rivers where the species occurs are in a critical situation. The drainages receive discharges of large amounts of sewage from pig farms, distilleries and the very intense agriculture of the surrounding area. Several massive fish kills have been documented in recent years. Intensive sampling by electrofishing failed to yield fish in these drainages, except for small isolated pockets located upstream of the major sources of pollution.

A taxon is considered Critically Endangered (CR) according to the IUCN Red List Categories (IUCN, 2001) when the best available evidence indicates that it meets any of the criteria A to E listed in Section V and it is therefore considered to be facing an extremely high risk of extinction in the wild. In our opinion, given the restricted number of known, fragmented and isolated populations, the low numbers of individuals present in each population and all the threats referred to above, this species should be catalogued in category $\mathrm{CR}$ following the criteria B1ab (i,ii,iii)+2ab (i,ii,iii).

\section{Discussion}

The results presented in this paper show that the populations of the rivers Sizandro and Safarujo differ from their northern neighbour $C$. oligolepis in morphology, osteology and in their mitochondrial genome, although each morphological variable taken separately does not allow an absolutely certain discrimination of the fish due to the presence of a few borderline individuals. These populations are still genetically more distant from their southern neighbour, C. lusitanicum. Although attempts of calibration of a molecular clock for the cytochrome $b$ of cypriniform fish have varied considerably, several authors have agreed in recent years with the estimate of $1.05 \%$ divergence per MYA $(0.53$ per lineage per MYA) (Doadrio \& Carmona, 2004; Dowling et al., 2002; Durand et al., 2003). Thus, the distances observed in this study clearly indicate that the populations of the rivers Alcabrichel, Sizandro and Safarujo diverged from C. oligolepis 5.55 MYA ago.

The recognition of $C$. occidentale as a new species means that the distribution of C. oligolepis ranges from the River Limia, in the north, south to the River Tornada. Concerning the population of the River Alcabrichel, its mitochondrial DNA places it unambiguously with $C$. occidentale. Meristic and morphometric data for this population are urgently needed to clarify its taxonomic status.

\section{ACKNOWLEDGMENTS}

The authors wish to thank V. Carvalho, A. Valente, G. Lemos and the Sousa Santos family for their help in sample collection. We appreciate the skilful technical assistance provided by F. Almada and V. Domingues and the help of T. Bento in maintaining live specimens. We also want to thank the referees of this paper for their invaluable criticisms and suggestions. Direcção Geral das Florestas provided the necessary authorizations for field work in Portugal. This study was funded by the projects "Evolution of feeding and agonistic behaviour in cyprinid fishes of the genus Chondrostoma" (funded by ISPA) and Plurianual Program (Fundação para a Ciência e Tecnologia, FCT, UI\&D 331/94, partially FEDER funded). C. Sousa Santos was also supported by a grant from FCT (SFRH/BD/8320/2002). J.I. Robalo and C. Sousa Santos benefited from grants from BiodIberia during the development of this study.

\section{References}

Alves, M. J., Coelho, M. M., Collares-Pereira, M. J. \& Dowling, T. E., 1997. Maternal ancestry of the Rutilus alburnoides complex (Teleostei, Cyprinidae) as determined by analysis of citochrome b sequences. Evolution, 51(5): 1584-1592.

Ayres, W. O., 1854. Descriptions of new species of fishes from California. Daily Placer Times and Transcript. Unpaginated.

Carmona, J. A., Domínguez, J. \& Doadrio, I., 2000. Congruence between allozymes and cytochrome b gene sequence in assessing genetic differentiation within the endemic Chondrostoma lemmingii (Pisces: Cyprinidae). Heredity, 84: 721-732.

CAsado, M. P., 1995. Sistematica del género Rutilus Rafinesque, 1820 en la Peninsula Iberica. PhD dissertation. Universidad Complutense de Madrid. Madrid. 438 pp.

Collares-Pereira, M. J., 1979. On the systematic position of the Iberian Cyprinidae forms arcasi (Steindachner, 1866) and macrolepidotum (Steindachner, 1866) of the genus Rutilus. Arquivos do Museu Bocage, VI(22): 361-394. 
Collares-Pereira, M. J., 1980. Les Chondrostome à bouche arquée de la Peninsule Ibérique (avec la description de Ch. lusitanicum nov. sp.) (Poisson, Cyprinidae). Comptes Rendus Hebdomadaires des Séances de l'Académie des Sciences, Série D, 291: 275-278.

Collares-Pereira, M. J., 1983. Estudo sistemático e citogenético dos pequenos ciprinídeos ibéricos pertenecentes aos géneros Chondrostoma Agassiz, 1835, Rutilus Rafinesque, 1820 e Anaecypris CollaresPereira, 1893. PhD dissertation. Universidade de Lisboa. Lisbon. 511 pp.

Costa Pereira, N., 1995. The freshwater fishes of the Iberian Peninsula. Arquivos do Museu Bocage, Nova Série, II(30): 473-538.

Diogo, R., 1999. Distribuição espacial das comunidades píscicolas da região hidrográfica ribeiras do Oeste e sua relação com os factores ambientais. Relatório de Estágio. Instituto Superior de Agronomia, Universidade Técnica de Lisboa. Lisboa. 54 pp.

DoADrio, I., 2001. Atlas y libro rojo de los peces continentales de España. Dirección General de la Natureza - Museo Nacional de Ciencias Naturales. Madrid. 364 pp.

DOADRIO, I. \& CARMONA, J. A., 2003. A new species of the genus Chondrostoma Agasiz, 1832 (Actinopterygii, Cyprinidae) from the Iberian Peninsula. Graellsia, 59(1): 29-36.

DoAdrio, I. \& CARMONA, J. A., 2004. Phylogenetic relationships and biogeography of the genus Chondrostoma inferred from mitochondrial DNA sequences. Molecular Phylogenetics and Evolution, 33: 802815.

Dowling, T. E., Tibbets, C. A., Minckley, W. L. \& SмiтH, G. R., 2002. Evolutionary relationships of the plagopterins (Teleostei: Cyprinidae) from cytochrome b sequences. Copeia, 2002(3): 655-678.

Durand, J. D., Bianco, P. G., Laroche, J. \& Gilles, A., 2003. Insight into the origin of endemic Mediterranean ichthyofauna - Phylogeography of Chondrostoma genus (Teleostean, Cyprinidae). Journal of Heredity, 94: 315-328.

ElviRA, B., 1987. Taxonomic revision of the genus Chondrostoma Agassiz, 1835 (Pisces, Cyprinidae). Cybium, 11(2): 111-140.

ElvirA, B., 1997. Taxonomy of the genus Chondrostoma (Osteichthyes, Cyprinidae): an updated review. Folia Zoologica, 46(suppl. 1): 1-14.

IUCN, 2001. IUCN Red List Categories and Criteria: Version 3.1. IUCN Species Survival Commission, IUCN. Gland and Cambridge. ii $+30 \mathrm{pp}$.

Machordom, A. \& DoAdrio, I., 2001. Evidence of a Cenozoic Betic-Kabilian connection based on freshwater fish phylogeography (Luciobarbus, Cyprinidae). Molecular Phylogenetics and Evolution, 18(2): 252-263.
Mesouita, N., Carvalho, G., Shaw, P., Crespo, E. \& Coelho, M. M., 2001. River basin-related genetic structuring in an endangered fish species, Chondrostoma lusitanicum, based on mtDNA sequencing and RFLP analysis. Heredity, 86: 253264.

Oliveira, R. F. \& Almada, V. C., 1995. Sexual Dimorphism and allometry of external morphology in the Mozambique Tilapia Oreochromis mossambicus (Teleostei, Cichlidae). Journal of Fish Biology, 46(6): 1055-1064.

RAFINESQUE, C. S., 1820. Ichthyologia Ohiensis [Part 5]. Western Review and Miscellaneous Magazine, 2(4): 235-242.

Robalo, J. I., Doadrio, I., Almada, V. C. \& Kottelat, M., 2005. Chondrostoma oligolepis, new replacement name for Leuciscus macrolepidotus Steindachner, 1866 (Teleostei: Cyprinidae). Ichthyological Exploration of Freshwaters, 16(1): 47-48.

Robalo, J. I., Sousa Santos, C., Almada, V. C. \& DoADrIO, I., In press. Paleobiogeography of two Iberian endemic cyprinid fishes (Chondrostoma arcasii - Chondrostoma macrolepidotum) inferred from sequence data. Journal of Heredity.

SAMBroOK, E., Fritsch, F. \& MANiATIS, T., 1989. Molecular Cloning. $2^{\text {nd }}$ edition. Cold Spring Harbour Press. Cold Spring Harbour. 1654 pp.

Schneider, S., Roessli, D. \& Excofier, L., 2000. Arlequin ver 2.000 - a software for population genetics data analysis. University of Geneva.

StatSoft, Inc., 1996. STATISTICA FOR Windows, RELEASE 5.1(COMPUTER PROGRAM MANUAL). StatSoft, Inc., Tulsa.

STEINDACHNER, F., 1866. Ichthyologischer Bericht über eine nach Spanien und Portugal unternommene Reise. (Zweite Fortsetzung.) über eine die Fische Tajo (portug. Tejo), Duero (portug. Douro), Minho portug. Minho), deren Nebebflussen und aus dem Jucar bei Cuenca. Sitzungsberichte der Akademie der Wissenschaften in Wien, Mathematisch-Naturwissenschaftliche Klasse, 54: 1-22.

SteIndACHNER, F., 1866. Ichthyologischer Berichtes über eine nach Spanien und Portugal Unternommene Reise II. Sitzungsberichte der Akademie der Wissenschaften in Wien, Mathematisch-Naturwissenschaftliche Klasse, 53: 198-205.

SwOFFORD, D. L., 1998. PAUP*. Phylogenetic analysis using parsimony (and other methods). Version 4. Sinauer Associates. Sunderland.

Thompson, J. D., Gibson, T. J., Plewniak, F., Jeanmougin, F. \& Higgins, D. G., 1997. The Clustal $\mathrm{X}$ windows interface: flexible strategies for multiple sequence alignment aided by quality analysis tools. Nucleic Acids Research, 24: 4876-4882. 
ZARDOYA, R. \& DoADRIO, I., 1998. Phylogenetic relationships of Iberian cyprinids: systematic and biogeographical implications. Proceedings of the Royal Society of London, Series B, 265: 13651372.

ZARDOYA, R. \& DoAdrio, I., 1999. Molecular evidence on the evolutionary and biogeographical patterns of european cyprinids. Journal of Molecular Evolution, 49: 227-237.
WASSERSUG, R. J., 1976. A procedure for differential staining of cartilage and bone in whole formalinfixed. Stain Technology, 51(2): 131-134.

Recibido, 23-XI-2004

Aceptado, 13-IV-2005 Publicado, 14-VII-2005 